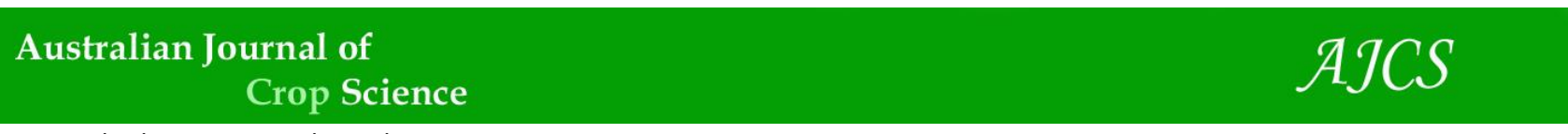

AJCS 11(10):1277-1282 (2017)

ISSN:1835-2707

doi: 10.21475/ajcs.17.11.10.pne542

\title{
Effects of plant growth regulators on eggplant seed germination and seedling growth
}

\author{
Francisco José Domingues Neto ${ }^{1}$, Samanta Jaqueline Dalanhol ${ }^{2}$, Marcos Machry $^{3}$, Adilson Pimentel \\ Junior $^{1}$, João Domingos Rodrigues ${ }^{2}$, Elisabeth Orika Ono ${ }^{2}$
}

${ }^{1}$ São Paulo State University (UNESP), School of Agriculture, José Barbosa de Barros, ${ }^{\circ}$ 1.780, ZIP: 18.610-307, Botucatu, SP, Brazil

${ }^{2}$ São Paulo State University (UNESP), Institute of Biosciences, Dr. Antônio Celso Wagner Zanin, s/n, ZIP: 18.618-689, Botucatu, SP, Brazil

${ }^{3}$ Faculty of Technology of Mogi das Cruzes, Carlos Barattino, $n^{\circ}$ 908, ZIP: 08.773-600, Mogi das Cruzes, SP, Brazil

\section{*Corresponding author: fjdominguesneto@hotmail.com}

\begin{abstract}
This study aimed at evaluating the germination and the growth of eggplant (cultivar 'Embu') seedlings submitted to imbibition in $\mathrm{GA}_{3}$ and $\mathrm{GA}_{4+7}+\mathrm{Benzyladenine}(\mathrm{BA})$. The experiment was carried out under laboratory and greenhouse conditions, adopting a completely randomized design, in a 2 x 6 factorial arrangement, i.e. two plant growth regulators $\left(\mathrm{GA}_{3}\right.$ and $\left.\mathrm{GA}_{4+7}+\mathrm{BA}\right)$ and six imbibition conditions (no imbibition, 0, 250, 500, 750, and $1000 \mathrm{mg} \mathrm{L}^{-1}$ a.i.). Germination percentage, mean germination time, germination speed index, first germination count, synchronization index, and germination frequency were determined in the laboratory. In greenhouse, evaluations consisted of emergence speed index, seedling height at 15, 30, and 45 days after imbibition; stem diameter at substrate surface level, leaf area, root and shoot dry matter, and Dickson quality index at 45 days. $\mathrm{GA}_{3}$ accelerated the seed germination process and the seedling emergence, and led to an increase in seedling height at $750 \mathrm{mg} \mathrm{L}^{-1}$ up to 30 days. For the mixture $\mathrm{GA}_{4+7}+\mathrm{BA}$, the results indicated phytotoxic effects, delaying seed germination and seedling formation. Thus, pre-soaking of eggplant seeds in $\mathrm{GA}_{3}$ at $750 \mathrm{mg} \mathrm{L}^{-1}$ is recommended.
\end{abstract}

Keywords: $\mathrm{GA}_{3 ;} \mathrm{GA}_{4+7}+$ Benzyladenine; Solanum melongena $\mathrm{L}$.

Abbreviation: $1^{\circ} \mathrm{GC}$ _first germination count; ABA_abscisic acid; BA_benzyladenine; DAS_days after sowing; DQI_Dickson quality index; ESI_emergence speed index; G_germination percentage; GA_gibberellin; GSI_germination speed index; MGT_mean germination time; RDM_root dry matter; SDM_shoot dry matter; U_synchronization.

\section{Introduction}

Eggplant (Solanum melongena L.) is a Solanaceae native to Asia and grown in several world regions, mainly with hot climates (González-Lavaut et al., 2007). Although the planted area is not significant in Brazil, there is an increasing in its consumption, motivated by the demand for healthier and medicinal products by consumers (Filgueira, 2000). In the production chain of high quality vegetables, seedling formation is one of the most important crop growth stages, directly influencing the final plant performance from a nutrition and production point of view, since there is a direct relationship between healthy seedlings and field production (Campanharo et al., 2006). Well-formed seedlings can increase production, whereas bad-formed ones can delay crop growth, thus resulting in losses to producers (Guimarães et al., 2002). Then, techniques leading to greater germination and physiological quality are important factors to improve seed performance potential and, consequently, plant uniformity under field conditions. The use of plant growth regulators in germination can result in greater seedling development, speeding emergence and enhancing seed potential (Lopes and Souza, 2008). In the germination process, gibberellins stimulate enzymatic synthesis and activity (Borghetti, 2004; Silva et al., 2005), favoring cell expansion and seedling growth (Marcos Filho, 2005). Gibberellins are also related to dormancy break in some species, since they are involved in induction of synthesis of enzymes responsible for endosperm weakening (Borghetti, 2004; Silva et al., 2005). Furthermore, they can stimulate the germination process of non-dormant seeds (Taiz and Zeiger, 2013). Cytokinins are not essential for seed germination. However, when applied, they can reduce the sensitivity of seeds to abscisic acid (ABA), a plant hormone responsible for maintaining dormancy (Hartmann et al., 2011).

This study aimed at evaluating the effects of plant growth regulators $-\mathrm{GA}_{3}$ and $\mathrm{GA}_{4+7}+\mathrm{BA}$ on the germination and the growth of eggplant (Solanum melongena $\mathrm{L}$.) seedlings.

\section{Results and Discussion}

Acquisition of water by seeds

The water acquisition curve indicated that eggplant seeds had $8.7 \%$ initial moisture content, which stabilized around $73 \%$ at $12 \mathrm{~h}$, time used subsequently for imbibition of seeds in 
plant growth regulators. The water acquisition by seeds follows a triphasic pattern, in which the first phase represents a fast water entry in response to their matric potential, the second phase indicates stabilization of water entry and increase in metabolic activity due to transcription of new genes, and the third phase represents radicle protrusion (Bewley et al., 2013).

In tomato seeds, Ferreira et al. (2013) observed that the second phase of the imbibition curve was reached at $25 \mathrm{~h}$, differing of our findings. This fact demonstrates the importance of studies on seed imbibition before immersion in plant growth regulators, since the two species showed a distinct imbibition pattern even belonging to the same family.

\section{Germination}

The use of $\mathrm{GA}_{3}$ up to $750 \mathrm{mg} \mathrm{L}^{-1}$ led to an increase in germination percentage in comparison with the control group (Fig. 1A) probably due to seeds present high vigor before their submission to treatments (Albuquerque et al., 2009). Eggplant ('Embu') seeds soaked in 400-ppm GA 3 solution presented $79.5 \%$ germination (Pimenta et al., 2010). The same authors soaked seeds in plant growth regulators for $6 \mathrm{~h}$, which can have led to lower germination, since in the present study the ideal time of seed imbibition was $12 \mathrm{~h}$ (Fig. 1).

To maintain their hormonal balance, plants can respond to GA by stimulating its deactivation through inhibition of expression of some genes related to bioactive GA biosynthesis (negative feedback) and induction of expression of genes involved in its deactivation (positive feedback) (Taiz and Zeiger, 2013). Thus, when in excess, GA is converted into inactive forms, which negatively affect germination (Bewley et al., 2013). This fact can justify the drastic reduction in germination under the influence of $\mathrm{GA}_{4+7}+\mathrm{BA}$ and at $1000 \mathrm{mg} \mathrm{L}^{-1} \mathrm{GA}_{3}$.

As to mean germination time, seeds soaked in $\mathrm{GA}_{3}$ presented similar results to those of the control group (approximately 3 days), while those submitted to $\mathrm{GA}_{4+7}+\mathrm{BA}$ showed prolonged time as higher concentration of such a mixture, with 11 days on average at $1000 \mathrm{mg} \mathrm{L}^{-1}$ (Fig. 1B). Mean germination time is useful to evaluate the speed of occupation by a species in a certain environment (Ferreira et al., 2001). Thus, the lower its value, the lower the time in which seeds is susceptible to adverse conditions. This fact was not observed under the influence of $\mathrm{GA}_{4+7}+\mathrm{BA}$, since such a mixture of plant growth regulators resulted in prolonged mean germination time because its concentration was higher.

$\mathrm{GA}_{3}$-treated seeds showed higher germination speed index (GSI) according to its higher concentration, presenting a mean value of 23 at $750 \mathrm{mg} \mathrm{L}^{-1}$. Seeds submitted to $\mathrm{GA}_{4+7}+\mathrm{BA}$ showed an opposite response, in which the same concentration led to a value of GSI around zero (Fig. 1C).

For sowing purposes, conditions providing fast and uniform seed germination need to be known. Thus, seedling care is reduced, since plants will present a faster and uniform development in the field, where they will be exposed to adverse environmental conditions (Pacheco et al., 2006). Therefore, seeds must be treated with $750 \mathrm{mg} \mathrm{L}^{-1} \mathrm{GA}_{3}$ in order to obtain eggplant seedlings in a shorter time interval.

First germination count increased up to $500 \mathrm{mg} \mathrm{L}^{-1} \mathrm{GA}_{3}$, followed by decrease from around $83 \%\left(500 \mathrm{mg} \mathrm{L}^{-1}\right)$ to $80 \%$ (1000 $\left.\mathrm{mg} \mathrm{L}^{-1}\right)$ of normal seedlings (Fig. 1D). The mixture $\mathrm{GA}_{4+7}+\mathrm{BA}$ did not result in the formation of normal seedlings, thus emphasizing its phytotoxic effect on eggplant seeds.
Such values disagreed with those found by Pimenta et al. (2010), who also evaluated eggplant cv. 'Embu' seeds and observed $3 \%$ for seeds soaked in water and $11 \%$ when submitted to $400 \mathrm{mg} \mathrm{L}^{-1} \mathrm{GA}_{3}$, thus demonstrating that distinct lots of eggplant cv. 'Embu' seeds can present significant differences in their germination performance.

\section{Germination frequency}

Unsoaked seeds and those soaked in water and in $\mathrm{GA}_{3}$ had an unimodal frequency distribution, concentrating their germination before five days, differing from seeds soaked in $\mathrm{GA}_{4+7}+\mathrm{BA}$, which showed asymmetric distribution, with a polymodal pattern, i.e. such seeds took longer to germinate and showed low synchronization (higher values) (Fig. 2). According to Borghetti and Ferreira (2004), this pattern is frequent in species living in adverse environments because seeds are more likely to germinate under a favorable condition when germination is distributed over time.

\section{Height of seedlings}

$\mathrm{GA}_{3}$ influenced positively on seedling height at 15 and 30 days after sowing (DAS), when all seeds soaked in $\mathrm{GA}_{3}$ showed higher height (Table 1), indicating that gibberellins lead to a faster initial growth of seedlings, which reach the height for transplanting earlier, thus decreasing their time in the nursery.

At 15 DAS, under $1000 \mathrm{mg} \mathrm{L}^{-1} \mathrm{GA}_{3}$, seedlings presented $2.3 \mathrm{~cm}$, similar only to the treatments $0 \mathrm{mg} \mathrm{L}^{-1}$ and with no imbibition, which showed $1.1 \mathrm{~cm}$ height.

Gibberellin acts in the activation of embryo vegetative growth, mobilization of endosperm reserves and weakening of the endosperm layer around embryo, thus favoring its growth (Taiz and Zeiger, 2013), which explains the higher height of seedlings from $\mathrm{GA}_{3}$-treated seeds.

The use of $\mathrm{GA}_{3}$ did not influence seedling height at 45 DAS, since no statistical difference was observed for any concentration applied. This fact can be due to $\mathrm{GA}_{3}$ absorbed by seeds has already been used in the initial phase of germination. Conversely, Silva et al. (2014) reported positive influence of $\mathrm{GA}_{3}$ on watermelon seedlings, since $\mathrm{GA}_{3}$-treated plants showed higher height in comparison with the control group, treated with distilled water. The same authors concluded that 50 and $100 \mu \mathrm{g} \mathrm{g}^{-1}$ GA led to a higher seedling shoot development. Growth-related responses were also observed in lettuce, in which seed application of 100, 200, and $300 \mathrm{mg} \mathrm{L}^{-1} \mathrm{GA}$ in addition to $0.80 \mathrm{MPa}$ osmotic conditioning resulted in higher seedling length (Menezes et al., 2006).

For growth-related variables, seedlings showed similar responses to those observed under laboratory conditions. The mixture $\mathrm{GA}_{4+7}+\mathrm{BA}$ also had phytotoxic effect on the growth of eggplant seedlings (Fig. 3). Similar results were observed by Bohorquez-Sandova et al. (2011) in tomato seedlings, in which $\mathrm{GA}_{3}$ led to better results for their growth than $\mathrm{GA}_{4+7}+\mathrm{BA}$.

\section{Index of emergency speed and stem diameter}

$\mathrm{GA}_{3}$-treated seeds showed higher emergence speed index (ESI), while no differences were observed among $\mathrm{GA}_{3}$ concentrations for stem diameter at substrate surface level. Albuquerque et al. (2009) studied the effect of $\mathrm{GA}_{3}$ on the growth of Capsicum annuum L. seedlings and observed that ESI also tended to be higher in seeds previously soaked in GA. 
Table 1. Height (cm) of eggplant seedlings (Solanum melongena L.) cv. Embu, at 15, 30 and 45 days after imbibition, treated with different concentrations of $\mathrm{GA}_{3}$.

\begin{tabular}{|c|c|c|c|c|c|c|}
\hline & \multicolumn{6}{|c|}{ Concentration of $\mathrm{GA}_{3}$} \\
\hline & No imbibition & $0 \mathrm{mg} \mathrm{L}^{-1}$ & $250 \mathrm{mg} \mathrm{L}^{-1}$ & $500 \mathrm{mg} \mathrm{L}^{-1}$ & $750 \mathrm{mg} \mathrm{L}^{-1}$ & $1000 \mathrm{mg} \mathrm{L}^{-1}$ \\
\hline 15 days & $1.1 \mathrm{~b}$ & $1.1 \mathrm{~b}$ & $1.5 \mathrm{ab}$ & $1.8 \mathrm{ab}$ & $2.1 \mathrm{ab}$ & $2.3 \mathrm{a}$ \\
\hline 30 days & $5.3 \mathrm{ab}$ & $5.2 \mathrm{~b}$ & $5.9 \mathrm{ab}$ & $5.9 \mathrm{ab}$ & $6.4 \mathrm{a}$ & $6.2 \mathrm{ab}$ \\
\hline 45 days & $9.4 \mathrm{a}$ & $9.7 \mathrm{a}$ & $9.6 \mathrm{a}$ & $9.9 \mathrm{a}$ & $10.4 \mathrm{a}$ & $9.7 \mathrm{a}$ \\
\hline
\end{tabular}

Means within lines followed by different letters differ significantly by Tukey’s test $(\mathrm{P}<0.05)$.

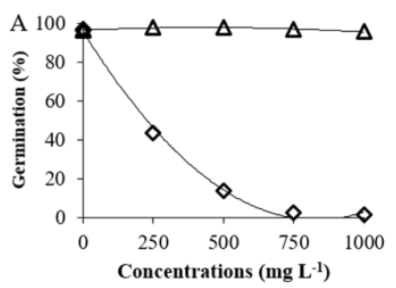
$\begin{aligned} \mathrm{GA}_{5} & =-8 \mathrm{E}-06 \mathrm{x}^{2}+0,0065 \mathrm{x}+96,288 \mathrm{R}^{2}=0,8881 \\ \mathrm{GA}_{4+2}+6-\mathrm{BA} & =0,0001 \mathrm{x}^{2}-0,2331 \mathrm{x}+95,591 \mathrm{R}^{2}=0,9983\end{aligned}$

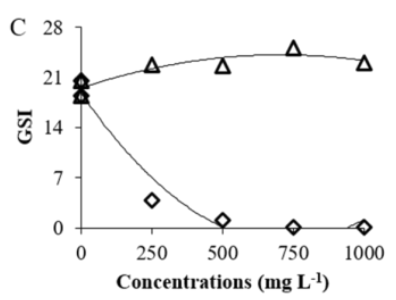
$\mathrm{GA}_{3}=-9 \mathrm{E}-06 \mathrm{x}^{2}+0,0131 \mathrm{x}+19,532 \mathrm{R}^{2}=0,8265$
$\mathrm{GA}_{4+7}+6-\mathrm{BA}=4 \mathrm{E}-05 \mathrm{x}^{2}-0,0569 \mathrm{x}+18,788 \mathrm{R}^{2}=0,9588$

$\Delta \mathrm{GA}_{3} \diamond \mathrm{GA}_{4+7}+6-\mathrm{BA}$

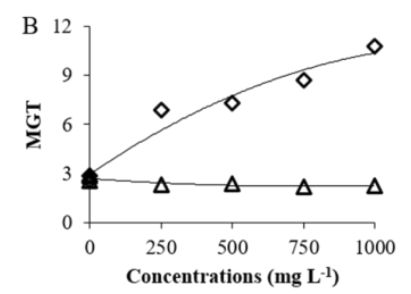

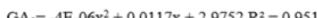

$\mathrm{GA}_{4+}+6-\mathrm{BA}=8 \mathrm{E}-07 \mathrm{x}^{2}-0,0012 \mathrm{x}+2,683 \mathrm{R}^{2}=0,7634$

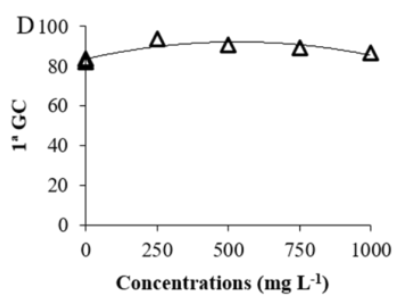

$\mathrm{GA}_{3}=-3 \mathrm{E}-05 \mathrm{x}^{2}+0,0323 \mathrm{x}+83,561 \mathrm{R}^{2}=0,7553$

Polynomial

Fig 1. Germination percentage (A), mean germination time (MGT - B), germination speed index (GSI - C) and first germination count ( $\left.1^{\mathrm{a}} \mathrm{GC}-\mathrm{D}\right)$ in eggplants seedlings (Solanum melongena L.), var Embu, treated with different concentrations of $\mathrm{GA}_{3}$ and $\mathrm{GA}_{4+7}$ + BA.
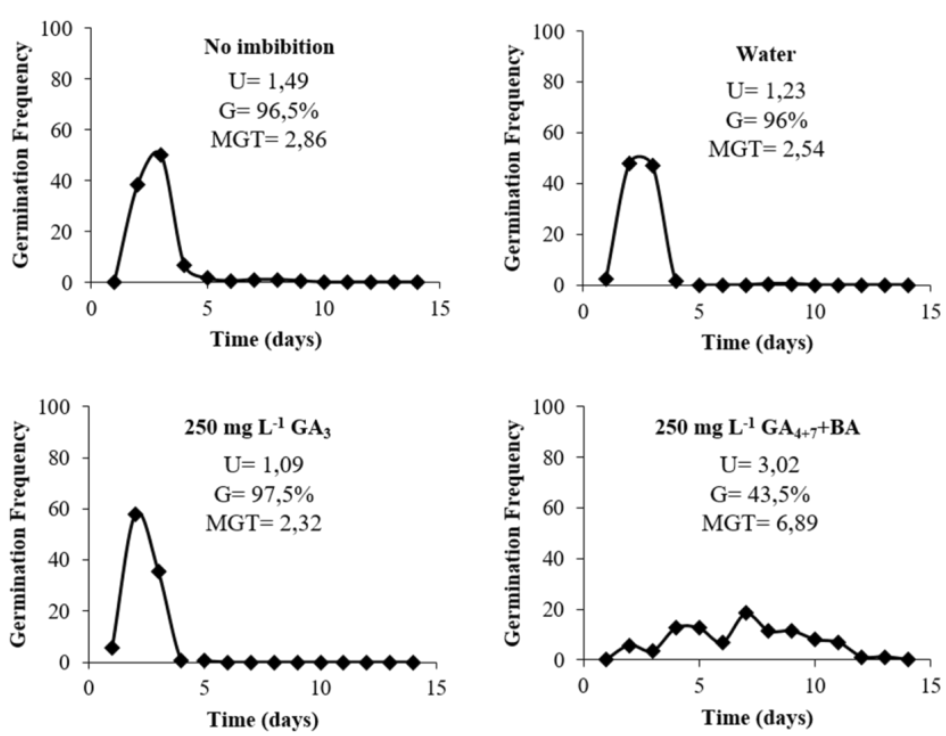

Fig 2. Synchronization (U) and germination frequency in eggplants seedlings (Solanum melongena L.), var Embu, no imbibition, imbibited on water and $250 \mathrm{mg} \mathrm{L}^{-1}$ of $\mathrm{GA}_{3}$ and $\mathrm{GA}_{4+7}+\mathrm{BA}$. 


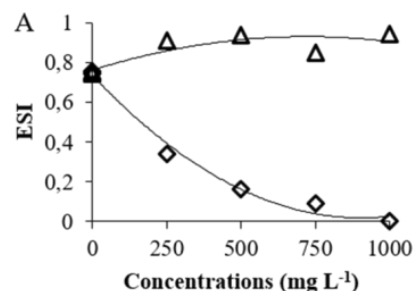

Concentrations ( $\mathrm{mg} \mathrm{L}^{-1}$ )

$\mathrm{GA}_{3}=-8 \mathrm{E}-06 \mathrm{x}^{2}+0,0065 \mathrm{x}+96,288 \mathrm{R}^{2}=0,8881$

$\mathrm{GA}_{4+7}+6-\mathrm{BA}=0,0001 \mathrm{x}^{2}-0,2331 \mathrm{x}+95,591 \mathrm{R}^{2}=0,9983$

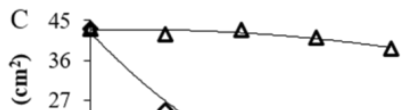

률

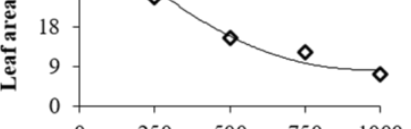

Concentrations $\left(\mathrm{mg} \mathrm{L}^{-1}\right)$

$G A_{3}=-8 \mathrm{E}-06 \mathrm{x}^{2}+0,0065 \mathrm{x}+96,288 \mathrm{R}^{2}=0,8881$ $\mathrm{GA}_{4+7}+6-\mathrm{BA}=0,0001 \mathrm{x}^{2}-0,2331 \mathrm{x}+95,591 \mathrm{R}^{2}=0,9983$

E 0,1

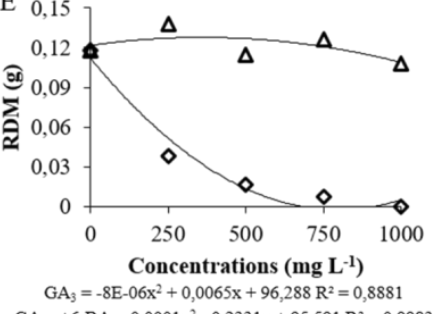

$\mathrm{GA}_{4}+6-\mathrm{BA}=0,0001 \mathrm{x}^{2}-0,2331 \mathrm{x}+95,591 \mathrm{R}^{2}=0,9983$

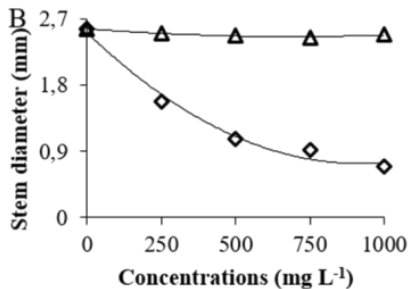

$G A_{3}=-4 E-06 x^{2}+0,0117 x+2,9752 R^{2}=0,9512$

$\mathrm{GA}_{4+1}+6-\mathrm{BA}=8 \mathrm{E}-07 \mathrm{x}^{2}-0,0012 \mathrm{x}+2,683 \mathrm{R}^{2}=0,7634$

D 0,45

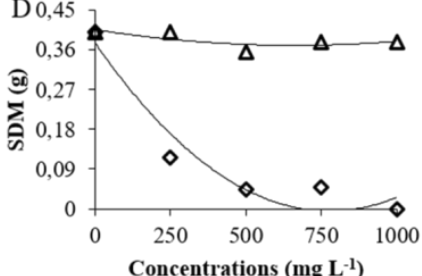

Concentrations ( $\left.\mathrm{mg} \mathrm{L}^{-1}\right)$

$\mathrm{GA}_{\mathrm{A}}=-4 \mathrm{E}-06 \mathrm{x}^{2}+0,0117 \mathrm{x}+2,9752 \mathrm{R}^{2}=0,9512$

$\mathrm{GA}_{4++}+6-\mathrm{BA}=8 \mathrm{E}-07 \mathrm{x}^{2}-0,0012 \mathrm{x}+2,683 \mathrm{R}^{2}=0,7634$

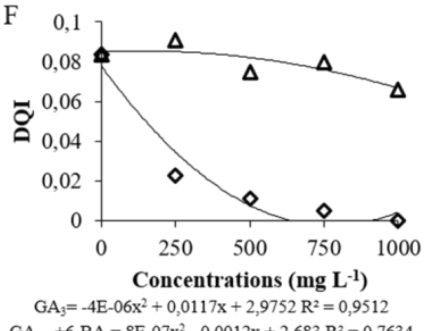

$\mathrm{GA}_{4}+\mathrm{T}+\mathrm{G}$

$\Delta \mathrm{GA}_{3} \diamond \mathrm{GA}_{4+7}+6-\mathrm{BA}$

Polynomial

Fig 3. Emergence speed index (ESI - A), stem diameter (B), leaf area (C), shoot dry matter (SDM - D), root dry matter (RDM - E) and Dickson quality index (DQI - F) in eggplants seedlings (Solanum melongena L.), var Embu, treated with different concentrations of $\mathrm{GA}_{3}$ and $\mathrm{GA}_{4+7}+\mathrm{BA}$.

In general, forest species present a strong correlation between survival rate of seedlings in the field and its stem diameter at substrate surface level, because they would be more susceptible to stresses if planted with reduced stem diameter at substrate surface level in the field, and practices after planting would be insufficient to increase their survival rate (Carneiro, 1995). Such information can also be valid for vegetable species, as observed in the present study, since seedlings from $\mathrm{GA}_{3}$-treated seeds showed higher stem diameter at substrate surface level, even than those observed in other studies on eggplant (Costa et al., 2011).

\section{Leaf area}

As to leaf area, once again $\mathrm{GA}_{3}$ led to better results for leaf growth of eggplant seedlings than $\mathrm{GA}_{4+7}+\mathrm{BA}$. BalagueraLopez et al. (2009) observed higher leaf area in tomato seedlings from seeds soaked in $\mathrm{GA}_{3}$. The same authors also reported that high $\mathrm{GA}_{3}$ concentrations might lead to an opposite effect, i.e. leaf area reduction. According to Monteiro et al. (2005), evaluation of leaf area is relevant since it can be used to investigate the productive capacity of the species.

\section{Dry matter}

$\mathrm{GA}_{3}$ concentrations resulted in few differences regarding root and shoot dry matter in the present study, while BalagueraLopez et al. (2009) observed that $300 \mathrm{mg} \mathrm{L}^{-1} \mathrm{GA}_{3}$ was already sufficient to increase dry matter of tomato seedlings.
Such biomass measurements are important for evaluating the quality of seedlings, since shoot dry matter indicates their hardiness and root dry matter can estimate their survival and initial growth in the field (Gomes; Paiva, 2011), which are directly related to their vigor.

\section{Dickson quality index}

Eggplant seedlings originated from seeds soaked in $250 \mathrm{mg}$ $\mathrm{L}^{-1} \mathrm{GA}_{3}$ presented higher quality based on Dickson quality index, with a slight decline in quality according to higher $\mathrm{GA}_{3}$ concentration. Costa et al. (2011) stated that this index is a good indicator for quality of seedlings because it considers several morphological traits such as height, stem diameter at substrate surface level and biomass, which is also recommended for eggplant seedlings.

\section{Materials and Methods}

\section{Location, plant materials and experimental design}

The experiments were carried out in the Department of Botany (Institute of Biosciences), São Paulo State University (UNESP), Botucatu, SP, Brazil. This region is classified as Cfa according to the Köppen climate classification, with mean temperature in the warmest month above $22{ }^{\circ} \mathrm{C}$. Physiological quality of eggplant (cv. 'Embu') seeds was evaluated under laboratory and greenhouse conditions. The seeds were previously stored for three months in plastic bags, before installing the experiment. For the two environments, 
the experimental design was completely randomized, in a $2 \mathrm{x}$ 6 factorial arrangement, i.e. two plant growth regulators $\left(\mathrm{GA}_{3}\right.$ $\left(\right.$ ProGibb $\left.^{\circledR}\right)$ and $\mathrm{GA}_{4+7}+$ Benzyladenine (BA) (Promalin $\left.{ }^{\circledR}\right)$ ) and six imbibition conditions (no imbibition, 0, 250, 500, 750 , and $1000 \mathrm{mg} \mathrm{L}^{-1}$ of active ingredient).

\section{Imbibition of seed and test in the laboratory}

To determine the imbibition time of seeds in plant growth regulators, the water imbibition curve of seeds was performed using four replicates of 25 seeds, immersed in distilled water with aeration system. At each period, seeds were removed from water, dried with paper superficially and weighed in balance with $0.0001 \mathrm{~g}$ readability. Then, the seed moisture content was determined by oven drying method at $105{ }^{\circ} \mathrm{C}$ (Brasil, 2009). The duration of the phase I was used for imbibing the seeds in the regulators.

For the germination test, four replicates of 50 seeds were placed into gerboxes with blotting paper as substrate and maintained in a germination chamber with alternate temperature and light $\left(16 \mathrm{~h}\right.$ light at $30^{\circ} \mathrm{C} / 8 \mathrm{~h}$ dark at $\left.20^{\circ} \mathrm{C}\right)$, according to Brasil (2009).

Seeds presenting at least $2 \mathrm{~mm}$ radicle protrusion were considered germinated (Hadas, 1976). Germination percentage, mean germination time (Laboriau, 1983), germination speed index (Maguire, 1962), first germination count (Brasil, 2009), synchronization index, and germination frequency (Labouriau and Agudo, 1987) were determined.

\section{Test in the greenhouse}

In the greenhouse test, four replicates of six seeds were placed into polystyrene trays with 72 cells $\left(100 \mathrm{~cm}^{3}\right)$ filled with commercial substrate consisting of sphagnum peat moss, vermiculite, limestone, and agricultural gypsum ( $\mathrm{pH} 5.0,0.7$ $\mathrm{mS} \mathrm{cm}$-1 electrical conductivity; $101 \mathrm{~kg} \mathrm{~m}^{-3}$ density; $55 \%$ water retention capacity (WRC)). Emergence speed index (Maguire, 1962), seedling height at 15, 30, and 45 days, stem diameter at substrate surface level, leaf area, root and shoot dry matter at 45 days after sowing (DAS), and Dickson quality index (also at 45 DAS) (Costa et al., 2011) were evaluated.

\section{Statistical analysis}

The results were submitted to the analysis of variance ( $F$ test), the polynomial regression analysis to show the responses of variables in function of plant growth regulator levels and the Tukey test $(p \leq 0.05)$ for comparison of means.

\section{Conclusion}

The treatment of eggplant seeds with $\mathrm{GA}_{3}$ led to higher height and speeded germination and seedling emergence in greenhouse. Thus, pre-soaking of eggplant seeds in $\mathrm{GA}_{3}$ at $750 \mathrm{mg} \mathrm{L}^{-1}$ is recommended. The mixture $\mathrm{GA}_{4+7}+\mathrm{BA}$ negatively affected all analyzed variables, since it presented phytotoxic effects regardless of its concentration, delaying seed germination and seedling formation.

\section{Acknowledgement}

We would like to thank the "Coordination of Improvement of Higher Level Personnel" (CAPES), for their financial support for this project.

\section{References}

Albuquerque KS, Guimarães RM, Gomes LAA, Vieira AR, Jácome MF (2009) Condicionamento osmótico e giberelina na qualidade fisiológica de sementes de pimentão colhidas em diferentes estádios de maturação. Rev Bras Sementes 31(4):100-109.

Balaguera-Lopez HE, Deaquiz YA, Álvarez-Herrera JG (2009) Plántulas de tomate (Solanum lycopersicum L.) provenientes de semillas embebidas en diferentes soluciones de giberelinas $\left(\mathrm{GA}_{3}\right)$. Agron Colomb. 27(1):5764.

Bewley JD, Bradford KJ, Hilhorst HWM, Nonogaki H (2013) Seeds: physiology of development, germination and dormancy, 3rd. New York, Springer.

Bohórquez-Sandoval C, Álvarez-Herrera JG, Niño-Medina RC (2011) Giberelinas y 6-bencilaminopurina en la plantulación de semillas de tomate (Solanum lycopersicum L.) híbrido adrale RZ F1. Temas Agrarios. 16(2):42-53.

Borghetti F (2004) Dormência embrionária. In: Ferreira AG, Borghetti F Germinação: do básico ao aplicado. Porto Alegre, Brasil, Artmed.

Borghetti, F, Ferreira AG (2004) Interpretação de resultados de germinação. In: Ferreira AG, Borghetti F Germinação: do básico ao aplicado. Porto Alegre, Brasil, Artmed.

Brasil. Ministério da Agricultura, Pecuária e Abastecimento (2009) Regras para análise de sementes. Brasília.

Campanharo M, Rodrigues JJV, Lira Junior MA, Espindula MC, Costa JVT (2006) Características físicas de diferentes substratos para produção de mudas de tomateiro. Caatinga. 19(2):140-145

Carneiro JGA (1995) Produção e controle de qualidade de mudas florestais. Curitiba, Brasil, UFPR/ FUPEF.

Costa E, Durante LGY, Nagel PL, Ferreira CR, Santos A (2011) Qualidade de mudas de berinjela submetida a diferentes métodos de produção. Rev Ciênc Agron. 42(4):1017-1025.

Ferreira AG, Cassol B, Rosa SGT, Silveira TS, Stival AL, Silva AA (2001) Germinação de sementes de asteraceae nativas no Rio Grande do Sul, Brasil. Acta bot bras. 15(2):231-242.

Ferreira RL, Forti VA, Silva VN, Mello SC (2013) Temperatura inicial de germinação no desempenho de plântulas e mudas de tomate. Ciên Rural. 43(7):1189-1195.

Filgueira, F. A. R (2000) Novo manual de olericultura. Agrotecnologia moderna na produção e comercialização de hortaliças. Viçosa, Brasil, UFV.

Gomes JM, Paiva HN (2011) Viveiros florestais (propagação sexuada). Viçosa, Brasil, UFV.

González-Lavaut JÁ, Oca-Rojas YM, Domínguez-Mesa MI (2007) Breve reseña de la espécie Solanum melongena L. Rev Cubana Plant Med. 12(3):1-13.

Guimarães VF, Echer MM, Minami K (2002) Métodos de produção de mudas, distribuição de matéria seca e produtividade de plantas de beterraba. Hortic Bras. 20(3):505-509.

Hadas A (1976) Water update germination of leguminous seeds under changing external water potential in osmotic solution. J Exp Bot. 27(1):480-489.

Hartmann HT, Kester DE, Davies Junior FT, Geneve RL (2011) Plant propagation: principles and practices, 8ed. New Jersey, Prentice Hall.

Labouriau LG (1983) A germinação de sementes. Washington, Organização dos Estados Americanos.

Labouriau LG, Agudo M (1987) On the physiology of seed germination in S.hispanica L. 1. temperature effects. An Acad Bras Ciênc. 59(1):37-56. 
Lopes HM, Souza CM (2008) Efeitos da giberelinas e da secagem no condicionamento osmótico sobre a viabilidade e o vigor de sementes de mamão (Carica papaya L.). Rev Bras Sementes. 30(1):181-189.

Maguire JD (1962) Speed of germination aid in selection and evaluation for seedling emergence and vigor. Crop Sci. 2(1):176-177.

Marcos Filho J (2005) Fisiologia de sementes de plantas cultivadas. Piracicaba, Brasil, Fealq.

Menezes NL, Espindola MCG, Pasqualli LL, Santos CMR, Frazin SM (2006) Associação de tratamentos prégerminativos em sementes de alface. FZVA. 13(1):1-11.

Monteiro JEBA, Sentelhas PC, Chiavegato EJ, Guiselini C, Santiago AV, Prela A (2005) Estimação da área foliar do algodoeiro por meio de dimensões e massa das folhas. Bragantia. 64(1):15-24.

Pacheco MV, Matos VP, Ferreira RLC, Feliciano ALP. Pinto KMS (2006) Efeito de temperaturas e substratos na germinação de sementes de Myracrodruon urundeuva Fr. All. (Anacardiaceae). Rev Árvore. 30(3):359-367.

Pimenta RMB, Carvalho TG, Carvalho RS, Dantas BF, Aragão CA (2010) Efeito da giberelina na qualidade fisiológica de sementes de berinjela. Hortic Bras. 28(1):4284-4288.

Silva EAA, Toorop PE, Nijsse J, Bewley JD, Hilhorst WM (2005) Exogenous gibberellins inhibit coffee (Coffea arabica cv. Rubi) seed germination and cause cell death in the embryo. J Exp Bot. 56(413):1029-1038.

Silva TCFS, Silva RCB, Silva JESB, Santos RS, Aragão CA, Dantas BF (2014) Germinação de sementes de melancia sob diferentes métodos de tratamento com reguladores vegetais. Sci Plena, 10(3):1-15.

Taiz L, Zeiger E (2013) Fisiologia Vegetal, 5ed. Porto Alegre, Brasil, Artmed. 